\title{
Social protection in Egypt: A policy overview
}

\author{
Maia Sieverding \\ Irene Selwaness
}

Follow this and additional works at: https://knowledgecommons.popcouncil.org/departments_sbsr-pgy

Part of the Demography, Population, and Ecology Commons, Health Economics Commons, International Public Health Commons, Labor Economics Commons, and the Social Policy Commons How does access to this work benefit you? Let us know!

\section{Recommended Citation}

Sieverding, Maia and Irene Selwaness. 2012. "Social protection in Egypt: A policy overview," Gender and Work in the MENA Region Working Paper no. 23. Cairo: Population Council. 
NUMBER 23

SEPTEMBER 2012

GENDER AND WORK IN THE MENA REGION

WORKING PAPER SERIES

Poverty, Job Quality and Labor Market Dynamics

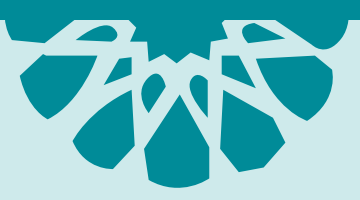

Social Protection in Egypt: A Policy Overview

Maia Sieverding and Irene Selwaness

(2) Population Council 
Maia Sieverding is a PhD student at UC Berkeley (and a former Population Council Employee). Email: msieverding@berkeley.edu

Irene Selwaness is a PhD student at Paris University. Email: irene.selwaness@gmail.com

The research presented in this publication is the result of a project funded by Canada's International Development Research Centre (www.idrc.ca).

\section{IDRC * CRDI}

Canadä

\section{(1) Population Council}

Research that makes a difference

The Population Council confronts critical health and development issues-from stopping the spread of HIV to improving reproductive health and ensuring that young people lead full and productive lives. Through biomedical, social science and public health research in about 50 countries, the Council works with our partners to deliver solutions that lead to more effective policies, programs, and technologies to improve lives worldwide. Established in 1952 and headquartered in New York, the Council is a nongovernmental, nonprofit organization with an international board of trustees.

Population Council

Egypt Country Office

59 Misr Helwan Agricultural Road, Maadi,

Cairo, Egypt

Tel.: (+202) 2525-5965, (+202) 2525-5967, (+202) 2525-5968

Facsimile: (+202) 2525-5962

Website: http://www.popcouncil.org

Email: pcouncil@popcouncil.org

(c) 2012 The Population Council, Inc.

Any part of this publication may be reproduced without permission for limited distribution, provided it is distributed without charge and the Population Council is acknowledged as its source. The Population Council would appreciate receiving a copy of any materials in which the text is used.

ISSN: 17931/2012 
NUMBER 23

SEPTEMBER 2012

GENDER AND WORK IN THE MENA REGION WORKING PAPER SERIES

Poverty, Job Quality and Labor Market Dynamics

\section{Social Protection in Egypt: A Policy Overview}

Maia Sieverding and Irene Selwaness 



\section{Table of content}

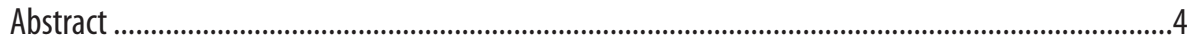

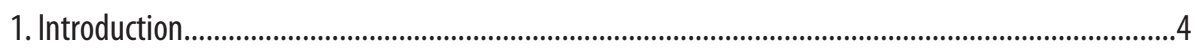

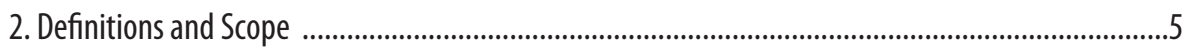

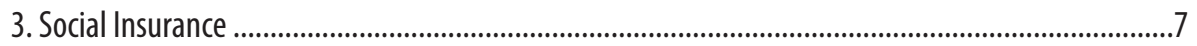

3.1 General Wage Workers Scheme (Law 79/1975) ..................................................................8

3.1.1 0ld age, disability and survivor benefits ............................................................. 9

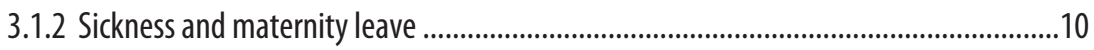

3.1.3 Workplace injury and unemployment ....................................................................11

3.2 Employers and Self-Employed Scheme (Law 108/1976) ..................................................... 11

3.3 Migrant Workers (Law 50 of 1978) and Casual Laborers (Law 112 of 1980) ........................... 12

3.4 Coverage and Shortcomings of the Social Insurance System .................................................. 13

3.5 Towards a New Social Insurance System: Law 135 of 2010 ................................................. 18

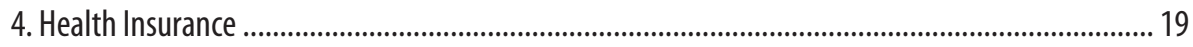

4.1 Coverage and Shortcomings of the Health Insurance System ............................................... 20

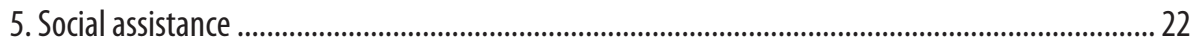

5.1 Coverage, Targeting and Shortcomings of the Social Assistance System .............................. 23

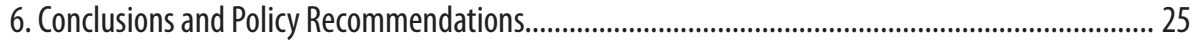

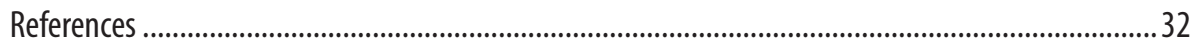




\section{Abstract}

The need to address the shortcomings of Egypt's current social protection system as part of a broader process of developing a new social contract between the Egyptian government and its citizens has been noted for a number of years. With a new government recently put in place, Egypt is now at a potential turning point in terms of implementing unfinished reforms to the system or proposing alternative ones. The aim of this paper is therefore to provide an overview and assessment of current public social protection mechanisms and suggest directions for new policy measures. The social and health insurance systems are covered, as well as the social assistance program that provides non-contributory pensions. Recommended policy measures to improve the current social protection system fall into three inter-related categories: strengthening the link between contribution and benefit levels, expanding coverage, and improving the administration of the system.

\section{Introduction}

Social protection is an important component of the social contract between a government and its citizens in any country. In Egypt, an extensive social protection system was one of the cornerstones of the state-centered social policy model developed in the I950s and i96os (World Bank 2006). This system, which includes social insurance, health insurance, and social assistance mechanisms, remains in place today without having seen any major reforms. ${ }^{\text {T }}$ The expansion of social protection under the current system was heavily based on growth in government employment and the extension of social protection benefits to public sector employees. However, the public-sector driven model proved unsustainable, and public sector employment has been sharply curtailed since the late i990s as part of a broader program of economic reform and structural adjustment (see Assaad, ed. 2009). The resulting informalization of the labor market and contraction of social insurance coverage, in combination with the failure of social assistance programs to reach a large percentage of the poor (UNDP 2005; World Bank 2006) have brought into question the efficacy of the current social protection scheme and the state's ability to provide for its citizens' basic welfare. Incomplete and unequal access to social protection

1 An extensive reform of the social insurance system, Law 135 of 2010, was passed and scheduled to come into effect in 2012. However, due to the events of the January $25^{\text {th }}, 2011$ revolution the status of this law is unclear. This issue will be discussed in detail below. 
mechanisms, in combination with the low quality of benefits delivered by these mechanisms, has furthermore led to the development of private markets for social goods and services that should be welfare rights (UNDP 2005).

The need to address the shortcomings of the current social protection scheme as part of a broader process of developing a new social contract between Egypt's government and its citizens has been noted by academics and development practitioners for a number of years (UNDP 2005). The events of the January $25^{\text {th }}, 20$ II revolution then dramatically demonstrated the extent to which Egypt's populace - and particularly its younger generations - had become disillusioned by the failures of the old policy regime. The demands issuing from Tahrir square for jobs, better working conditions, and measures to combat poverty all reflect, in part, the failures of the existing social protection system. With a new government being put in place, Egypt is now at a potential turning point in terms of implementing unfinished reforms or proposing alternative ones. In this context, the aim of this paper is to provide an overview and assessment of current public social protection mechanisms and suggest directions for new policy measures.

The remainder of the paper proceeds as follows: Section 2 briefly reviews the concept of social protection and discusses the scope of the paper; Section 3 describes the social insurance system in Egypt, including the legal framework, coverage and shortcomings; Section 4 describes the health insurance system and some of its shortcomings, and Section 5 addresses the public social assistance program that provides non-contributory pensions. Section 6 concludes and provides policy recommendations for the reform of Egypt's social protection system.

\section{Definitions and Scope}

The concept of social protection came to prominence after the wave of structural adjustment programs that swept through the Global South in the I990s. As the negative consequences of these programs for poverty became clearer, the social protection framework sought to develop a more comprehensive approach to poverty and vulnerability than the previous focus on social safety nets (Barrientos and Hulme 2009; Kabeer 2009). Much of the existing literature on social protection has focused on Latin America, and, to a lesser degree, South and East Asia. However, the conditions of high levels of poverty and vulnerability, as well as increasing labor market informalization, that have motivated the study of social protection in these other regions also prevail in Egypt and elsewhere in the 
Middle East and North Africa (MENA) (see World Bank 2007; Assaad, ed. 2009). It is therefore important to start bringing this region further into the social protection literature.

A variety of definitions for social protection have been put forward, primarily by international development agencies. ${ }^{2}$ According to Norton et al. (2002: 543), common elements across these definitions are a concern with addressing risk and vulnerability, as well as absolute deprivation, through measures that are "both social and public in character." In this paper, we follow the ILO's rights-based conception of social protection, under which social protection is defined as the "entitlement to benefits that society provides to individuals and households - through public and collective measures - to protect against low or declining living standards arising out of a number of basic risks and needs" (van Ginneken $2003 \mathrm{~b}$, p. II, cited in Barrientos and Hulme 2009). Put in another way, social protection is designed to insure against vulnerability to sudden losses of income associated with both expected and unexpected life events such as health crises, disability, old age, maternity, or unemployment (ILO 2009). A key element of this rights-based approach is that it conceives of social protection as part of a state's obligations to its citizens, rather than a set of optional policy mechanisms (Barrientos and Hulme 2009).

Although the proliferation of definitions has led to different understandings of what policies and programs are encompassed by social protection, the two core elements are social insurance and social assistance (Kabeer 2009). Social insurance is typically, although not necessarily, employment-based, financed by contributions from workers and employers. It provides insurance against contingencies such as maternity, sickness, and disability, as well as old age, through risk pooling. Social assistance consists of transfers to the poor or other defined population groups usually identified by a form of deprivation. In its public forms, social assistance is typically tax financed. Social assistance mechanisms may consist of pure income transfers (such as non-contributory pensions) or transfers conditional on labor supply or human capital investment (Norton et al. 2002; Barrientos 201I). The latter approach has been popularized in recent years through Conditional Cash Transfer (CCT) programs.

In addition to these two core categories, a range of other mechanisms have been considered by some to fall under the umbrella of social protection, including labor market regulations, employment support such as public works programs, consumer subsidies, and microfinance (Norton et al. 2002). These constitute a 'grey area' of instruments that fulfill some

2 For discussions of the role of these different international organizations in promoting social protection, and their respective definitions of the concept, see Norton et al. (2002) and Kabeer (2009). 
of social protection's aims but are not social insurance or social assistance (Kabeer 2009). We exclude these mechanisms from our discussion in this paper, focusing on social insurance and public social assistance in the form of non-contributory pensions. These two forms of social protection are the most widely accessed by households in Egypt. ${ }^{3}$ Consumer subsidies, probably the most prominent of the grey area mechanisms in the Egyptian context, have been extensively covered in other literature (see, e.g., Ahmed et al. 200I; World Bank 20IO; Fattouh and El Katiri 20I2).

\section{Social Insurance}

After the 1952 revolution, Egypt put into place a stratified social insurance system. The system was originally a fully-funded scheme in which employees' contributions were invested and returned as old age pensions, but has gradually shifted to become a partially funded Pay-AsYou-Go (PAYG) system that receives support from the Treasury. Under the PAYG system, current benefits for retirees and other beneficiaries are paid from the contributions of current workers. Egypt's pension system is a defined benefits scheme, i.e. pensions are equal to a set percentage of the average monthly wage earned (UNDP 2005).

Egypt has a complex social security system, with different schemes for different groups of workers. The National Organization for Social Insurance (NOSI) is responsible for managing the two social insurance funds; the Government Social Fund (GSF), which encompasses civil servants, and the Public and Private Business Sector Fund (PPBSF), which covers all other categories including private and public sector employees, employers, the self-employed and Egyptians working abroad. Both funds' budgets are independent of the state budget and are supervised by the Ministry of Social Solidarity (formerly the Ministry of Insurance and Social Assistance) (Maait et al. 200o).

Egypt's social insurance system is fragmented into several schemes that cover different types of workers. The overall system is regulated by four major laws that correspond to the four main schemes; Law 79 of 1975, Law 108 of 1976, Law 50 of 1978 , and Law II2 of 1980. These laws provide coverage for public and private sector wage workers, employers and the self-employed, Egyptians working abroad, and irregular or "unorganized" workers, respectively (Helmy 2004; SSA 20II). Taken together, the entirety of the social insurance system is classified by the

3 Although private social assistance through NGOs and religious organizations is likely quite extensive in the MENA region, these transfers are as of yet not well documented (World Bank 2006). 
ILO as "semi-comprehensive," providing old age, disability, survivors, sickness, maternity, employment injury and unemployment benefits but not family allowances (ILO 2010: 203). However, eligibility for these benefits differs across scheme. While the public and private sector wage workers scheme (Law 79 of 1975 ) provides insurance against all of the above-mentioned risks, the other schemes provide benefits only in case of old age, disability, and survivorship. A significant reform of the social insurance system was passed through Law 135 of 2010 , but this law has not yet been implemented and its status is unclear due to the events of the January $25^{\text {th }}$, 2OII revolution.

\subsection{General Wage Workers Scheme (Law 79/1975)}

Law 79 of 1975 outlines the general scheme for the social insurance system, insuring all government, public sector and formal private sector employees. The law makes social insurance coverage mandatory for all workers age 18 and above in the public and formal private sectors, and those age 16 and above in the government (SSA 20II). Employers are responsible for enrolling their employees in the system.

Employees' contributions are deducted from two types of monthly wage earnings: the base wage and the variable wage. ${ }^{4}$ The original law established a cap on the base and variable salaries used for calculating contributions, i.e. the maximum pensionable salary. This maximum bound is changed periodically to adjust for inflation and the cost of living. As of 2008, it was set at 775 Egyptian pounds (LE) for the base wage and $500 \mathrm{LE}$ for the variable wage (SSA 2009). Following the January $25^{\text {th }}$ revolution, reform measures implemented by the Ministry of Finance raised these maximum pensionable salary levels to $875 \mathrm{LE}$ for the base wage and I,050 LE for the variable wage (SSA 20II). In July 20I2, the new Minister of Social Solidarity passed Decree No. IO2 stipulating an annual increase of $15 \%$ on the maximum pensionable variable wage, in addition to immediately raising the cap on the pensionable variable wage to $\mathrm{I}, 200$ $\mathrm{LE}$ and on the pensionable base wage to $900 \mathrm{LE}$. Thus, the monthly wage

4 Salaries in Egypt are typically calculated as a base wage, which remains constant from month to month, and a variable wage, which includes bonuses, incentives and profit shares and other forms of compensation that are not constant (SSA 2011). 
used to calculate social insurance contributions currently has a maximum bound of 2,IOO LE. 5

Contributions are set as a fixed percentage of the pensionable wage, i.e. the wage reported to the social insurance authority up to the set maximum levels. The total contribution amounts to $4 \mathrm{r} \%$ of the basic wage and $25 \%$ of the variable wage, distributed between the employee, the employer, and the government. For the combination of old age, disability and survivors benefits, employees contribute $13 \%$ and $10 \%$ of the base and variable salary, respectively, whereas employers contribute $17 \%$ and $15 \%$ of the base and variable, respectively. The government contributes $\mathrm{I} \%$ of the base salary in addition to covering any deficit in the system. For sickness and maternity insurance, employees and employer contribute $\mathrm{r} \%$ and $4 \%$ of the base salary, respectively. Employers alone bear the cost of workplace injury and unemployment insurance, at $3 \%$ and $2 \%$ of the base wage, respectively. Thus, total contribution rates on the basic wage reach I $4 \%$ for the employee, $26 \%$ for the employer, and $\mathrm{I} \%$ for the government (Helmy 2004).

\subsubsection{Old age, disability and survivor benefits}

Old age pensions may be claimed by insured persons who meet the eligibility criteria of being 60 years old (the mandatory retirement age in the public sector) with 120 months of contributions, or any age with 240 months of contributions. A proportional reduction in pension value is made in the case of early retirement before age 60 (Helmy 2008; SSA 20II). The eligibility requirement for a disability pension is three months of consecutive contributions or a total of six months of contributions, provided that the disability occurred while the individual was contributing to social insurance or is within a year of leaving covered employment. If the disability occurred more than a year after leaving covered employment, Io years of past contributions are required in order to claim a pension (SSA 20II).

Pensions are calculated through a defined benefit method based on the basic and variable wages. The base pension is $1 / 45^{\text {th }}$ of the monthly base reference wage multiplied by the number of years of contributions up to 36 years. For public sector employees, the base reference wage for this calculation is the average of the base monthly wage in the two years prior

5 National Organization for Social Insurance announcement of 7 Juley 2010. Available at: http://nosi.gov.eg/ Arabic/News/Pages/\%D8\%B1\%D9\%81\%D8\%B9\%D8\%A7\%D9\%84\%D8\%AD\%D8\%AF\%D8\%A7\%D9\%8 4\%D8\%A3\%D9\%82\%D8\%B5\%D9\%89\%D9\%84\%D8\%A3\%D8\%AC\%D8\%B1\%D8\%A7\%D9\%84\%D8\%A5 \%D8\%B4\%D8\%AA\%D8\%B1\%D8\%A7\%D9\%83\%D8\%A7\%D9\%84\%D9\%85\%D8\%AA\%D8\%BA\%D9\%8A \%D8\%B1.aspx 
to employment, up to the maximum bound of the insurable wage (e.g. 875 LE in 2OII). For private sector employees, the reference wage is either the average monthly wage in the last two years or the average monthly wage during the five years prior to the last two years multiplied by I.4, whichever is smaller, again up to the maximum level in that year. Variable pensions are calculated as a fraction of the average monthly variable wage, with a higher percentage for dangerous work, over the entire contribution period increased by $2 \%$ for each year of contributions, also up to the maximum bound on the insurable variable wage (e.g. I,O5O LE in 20II). The maximum pension is set at $80 \%$ of the average monthly (base plus variable) wage (SSA 20II).

Survivor benefits are calculated according to the same formula as old age and disability pensions. Benefits are divided among eligible dependent family members, who are widows, disabled widowers, parents, able-bodied sons or brothers under age 2I (26 if a student), and disabled sons or brothers, unmarried sisters and unmarried daughters of any age. An additional clause provides for divorced spouses who were married to the deceased pensioner for at least 20 years and have no other source of income (SSA 2OII).

In addition to a pension, insured workers may be eligible to receive other benefits, such as a supplement for contribution periods exceeding 36 years and/or a lump-sum payment at the time of retirement or disability (SSA 20II). Individuals who contributed to the system may also receive a settlement, i.e. claim their social insurance contributions, under certain conditions if they withdraw from the labor force without having made sufficient contributions to receive a pension. Women are eligible to receive this settlement at any point with the presentation of a marriage certificate and other required paperwork. Men are eligible to receive a settlement upon reaching age 50 or 60 without having made sufficient contributions to receive a pension, or in selected other cases including imprisonment, emigration, and if his workplace goes bankrupt. ${ }^{6}$

\subsubsection{Sickness and maternity leave}

Employees covered under social insurance Law 79 of 1975 are eligible for a sickness benefit equal to $75 \%$ of the last covered wage for up to three months, and $85 \%$ of the wage for up to an additional three months. Contributions must have been paid for the last three months or for at least six months total, including the past two months, to be eligible for this benefit. This sickness benefit is unrelated to health insurance, which is discussed below (SSA 2OII).

6 Interview with a representative of the Social Insurance Administration, 25 June 2012. 
Women covered under social insurance are also legally entitled to three months of paid maternity leave for each of up to three children, provided they have contributed to social insurance for the prior io months. Maternity benefits are paid at $75 \%$ of the last covered wage (SSA 2OII). In addition, women working in establishments with more than 50 employees are entitled to up to two years of unpaid childrearing leave per child under Egyptian labor law. Female workers in all establishments are also entitled to two half-hour long nursing breaks per day, or one combined hour long break, for 24 months after the date of birth of each child. ${ }^{7}$

\subsubsection{Workplace injury and unemployment}

All workers covered by social insurance are eligible for a workplace injury benefit; there are no eligibility criteria in terms of contributions made. For temporary disabilities, I00\% of the wage is paid from the day after the injury until the worker is either able to return to work or is certified as permanently disabled. For permanent disabilities, the worker receives a benefit equal to $80 \%$ of the monthly base wage in the year before the disability occurred, with a cap of $875 \mathrm{LE}$ (the maximum pension bound in 2OII) on the wage used to calculate the benefit. For partial disabilities, a percentage of the benefit is paid according to the assessed percentage of the disability (SSA 20II).

Unemployment benefits are available to workers who have made at least six months of contributions, including the three months immediately prior to unemployment, and who did not leave work voluntarily or as the result of misconduct or the refusal of a suitable job offer. Unemployed persons must also be ready to work and registered with the manpower office. Benefits are equal to $60 \%$ of the last monthly wage for up to I6 weeks, or up to 28 weeks if the insured has made at least 24 months of contributions (SSA 20II). However, it is worth noting that the existence of this benefit does not seem to be widely known and it appears to be very rarely received (Sieverding 20I2).

\subsection{Employers and Self-Employed Scheme (Law 108/1976)}

Law Io8 of 1976 extends mandatory social insurance coverage for old age, disability and survivors benefits to employers and the self-employed age 2I to 65 (Maait et al. 2000). The other benefits afforded to formal public and private sector workers, including as maternity leave, health insurance, and workplace injury insurance, do not apply to employers and the self-employed (Helmy 2004). Covered categories of workers include the self-employed in the commercial, industrial and agricultural sectors,

7 Labor law Number 12 of 2003, available at http://www.egypt.gov.eg/english/laws/pdf/Book2.pdf 
members of production cooperatives who are working on their account, owners of real estate that yields at least 250 LE yearly, owners of means of transportation, operators of home-based industries employing one or more persons, farmers who own Io feddans or more, and owners of fishing boats employing one or more persons. ${ }^{8}$

The self-employed must declare their own level of insurable income, with the monthly contribution set at $15 \%$ of the declared income. The limit on declared income is I,O०० LE monthly. ${ }^{9}$ Pension eligibility is at age 65 with $\mathrm{I} 2 \mathrm{O}$ months of contributions. ${ }^{\mathrm{IO}}$ As with waged employees, pensions are calculated as $\mathrm{I} / 45^{\text {th }}$ of the monthly pensionable income chosen (or the average monthly income if the declared level was ever changed), multiplied by the number of years contributing. The minimum pension is $50 \mathrm{LE}$ per month and the maximum is $80 \%$ of the pensionable income chosen (Maait et al. 2000). Early retirement is possible for the self-employed, with associated deductions in the pension amount, as it is with waged employees. ${ }^{\text {II }}$

\subsection{Migrant Workers (Law 50 of 1978) and Casual Laborers (Law 112 of 1980)}

A system very similar to that for the self-employed and employers, with nearly identical eligibility requirements and benefits, also exists for Egyptians working abroad, as established by Law 50 of 1978 , with the major difference that for this group social insurance enrollment is voluntary (Helmy 2008). Casual and irregular laborers - or all those not covered by another social insurance scheme - are legally required under Law II2 of I980 to register with the Comprehensive Social Insurance System (CSIS). As with employers, the self-employed and migrants, this scheme for casual laborers insures only for old-age, disability and survivors benefits. Contributions are made through the purchase of a I LE stamp per month from one of the NSIO offices. Pensions are disbursed as a flat rate $63 \mathrm{LE}$ per month payment to those who have contributed for at least 120 months (Loewe 2004). As with the social assistance pensions (commonly known as Sadat pensions) that were established under Law II2 (see below), the CSIS was intended primarily as an income support mechanism for those not covered by one of the other three social insurance schemes described

8 Law 108 of 1976.

9 Interview with a representative of the Social Insurance Administration, 25 June 2012.

10 Law 108 of 1976.

11 lbid. 
above, and its contributions are supplemented by state resources in order to cover pension costs (Maait et al. 2000).

\subsection{Coverage and Shortcomings of the Social Insurance System}

The current social insurance system was expanded considerably with the extension of public sector employment in the r970s and I980s, due to the fact that all public sector employees are automatically enrolled in both the social and health insurance systems. Fairly high levels of social insurance coverage were therefore achieved among the cohorts that benefitted from the government hiring schemes implemented during this period. However, as shown in Table IA, current social insurance coverage declines significantly among younger groups in the population, from a high of $62.5 \%$ among male workers age $50-59$ in 2006 to $20.0 \%$ among male workers aged $20-29 .{ }^{12}$ This trend is attributable to the decline of public sector hiring in Egypt and resulting expansion of informal employment, which, by definition, does not provide social insurance coverage. In addition, social insurance coverage is lower among rural workers across all age groups, reaching a high of only $46.5 \%$ among those aged $40-49$ in 2006. Among rural workers aged $25^{-29}$, only a fifth had social insurance coverage

However, for women, social insurance coverage among workers may be a poor indication of personal coverage, or coverage in the individual's own name, for the population as a whole. This is attributable to the fact that labor force participation rates among women in Egypt, particularly in the formal sector, are quite low (Assaad and El Hamidi 2009). As shown in Table $\mathrm{IB}$, this has a significant effect on social insurance coverage, as proxied through current social insurance contributions, ${ }^{13}$ for the female population as a whole. Using this adjusted measure of coverage, social insurance barely exceeds $20 \%$ for any age group of women, and declines to as little as $3.7 \%$ among those $20-29$.

12 Figures for the youngest two age groups ( $15-19$ and $20-29)$ in Tables $1 A$ and $1 B$ may be somewhat underestimated because a portion of individuals in these age groups are still in school, and the more educated may have higher likelihood of obtaining social insurance through their employment.

13 Note that this calculation includes only those who are currently contributing to social insurance, not those who are currently receiving a pension, so under-estimates the total number of people with individual social insurance coverage. 
Table 1A: Percentage of workers with current personal enrollment in social insurance, by age group, gender and residence (2006)

\begin{tabular}{|lcc|cc|c|}
\hline & Male & Female & Urban & Rural & Total \\
\hline Age Group & & & & & \\
$15-19$ & 1.9 & 0.00 & 2.1 & 1.2 & 1.35 \\
$20-29$ & 20.0 & 25.9 & 33.6 & 19.7 & 22.0 \\
$30-39$ & 47.2 & 45.2 & 59.9 & 36.2 & 46.7 \\
$40-49$ & 61.5 & 53.5 & 73.5 & 46.5 & 59.2 \\
$50-59$ & 62.5 & 44.6 & 77.3 & 40.8 & 58.2 \\
\hline Total & $\mathbf{4 0 . 6}$ & $\mathbf{3 8 . 7}$ & $\mathbf{5 6 . 2}$ & $\mathbf{2 8 . 4}$ & $\mathbf{4 0 . 2}$ \\
\hline
\end{tabular}

Table 1B: Percentage of total population with current personal enrollment in social insurance, by age group, gender and residence (2006)

\begin{tabular}{|lcc|cc|c|}
\hline & Male & Female & Urban & Rural & Total \\
\hline Age Group & & & & & \\
$15-19$ & 0.0 & 0.0 & 0.0 & 0.0 & 0.0 \\
$20-29$ & 12.3 & 3.7 & 11.1 & 5.6 & 7.8 \\
$30-39$ & 45.3 & 14.2 & 38.4 & 24.1 & 30.6 \\
$40-49$ & 59.3 & 20.1 & 48.5 & 31.4 & 39.6 \\
$50-59$ & 55.5 & 11.4 & 42.0 & 23.1 & 32.3 \\
\hline Total & $\mathbf{2 0 . 1}$ & $\mathbf{5 . 7}$ & $\mathbf{1 8 . 0}$ & $\mathbf{9 . 1}$ & $\mathbf{1 2 . 9}$ \\
\hline
\end{tabular}

Note: Age groups over 60 are excluded from the table as this is the mandatory retirement age for the public sector in Egypt

Source: Authors' calculations from the 2006 Egypt Labor Market Panel Survey

Gaps in individual social insurance coverage could be mitigated through receipt of survivor benefits or shared benefits that will cover more than one individual during retirement. Table 2 shows that just under twothirds of male-headed households in which the head is age 60 or above were currently receiving a pension compared to $66.2 \%$ of female-headed households in the same age group. A significant percentage of femaleheaded households in which the head was under 60 were also receiving pensions, many of which are likely survivors' benefits given the fairly low rate of female labor force participation. 
Table 2: Percentage of households currently receiving a social insurance pension, by age and sex of household head and region of residence

\begin{tabular}{|lc|c|}
\hline & Male Head of Household & Female Head of Household \\
\hline Age Group & & \\
$25-29$ & 4.7 & 4.4 \\
$30-39$ & 4.5 & 27.8 \\
$40-49$ & 8.3 & 46.2 \\
$50-59$ & 14.6 & 56.6 \\
$60+$ & 62.1 & 66.2 \\
\hline Residence & & \\
Urban & 22.6 & 65.7 \\
Rural & 13.2 & 34.2 \\
\hline Total & $\mathbf{1 7 . 7}$ & $\mathbf{5 1 . 0}$ \\
\hline
\end{tabular}

Table 3: Percentage of households in which at least one member is currently enrolled in social insurance or currently receiving a pension, by age of household head (2006)

\begin{tabular}{|l|cc|c|}
\hline Age Group of Household Head & Urban & Rural & Total \\
\hline $25-29$ & 50.7 & 26.6 & 37.2 \\
$30-39$ & 61.3 & 45.2 & 52.6 \\
$40-49$ & 74.4 & 57.7 & 65.6 \\
$50-59$ & 84.1 & 55.3 & 69.7 \\
$60+$ & 84.9 & 55.8 & 71.9 \\
\hline Total & $\mathbf{7 3 . 3}$ & $\mathbf{4 9 . 2}$ & $\mathbf{6 1 . 0}$ \\
\hline
\end{tabular}

Taking current pension receipt and social insurance enrollment (as an indicator of the future right to a pension) together, Table 3 shows the percent of households who were either currently receiving a pension or had at least one member enrolled in social insurance as of 2006 . This measure shows that social insurance coverage reaches its highest levels $(84.9 \%)$ among older urban households. Among rural households, in contrast, the highest coverage rates are seen among households in which the head is age $40-49$, at $57.7 \%$. Coverage levels among households headed by an individual age $20-25$ are considerably lower, at $50.7 \%$ for the urban population and $26.6 \%$ for the rural population. A major challenge facing the social insurance system is thus to increase coverage among these youngest households.

In fact, Egypt benefits from a large youth population that, if enrolled in social insurance, could contribute greatly to ensuring the system's 
financial health (UNDP 2005). This financial aspect adds an additional incentive to increasing social insurance enrollment among younger workers, in addition to the issue of providing greater security for their families. However, as the system presently functions, evasion from social insurance contributions has a significant negative impact on the total value of contributions. Figures from the Ministry of Insurance in 2003, (cited in Helmy 2004) suggest that $30 \%$ of private sector companies either do not pay social insurance contributions for their employees at all, or pay contributions for only some of their employees, and that $40 \%$ of private sector employers and employees report a salary to social insurance that is less than their actual salary.

In terms of discouraging evasion and increasing incentives to social insurance participation, one of the most important shortcomings of the current social insurance system is that it acts as a regressive tax due to the cap/ceiling on pensionable wages explained above. In other words, low-wage workers pay contributions on their full earnings while highwage workers whose earnings exceed the legal pensionable wage ceiling pay contributions on only a part of their wage. Low-wage workers therefore have even more of an incentive to underreport their wages to evade the high contribution levels. In addition, by putting a ceiling on the pensionable wage, the system loses part of the contributions that could have been collected from the high-wage workers if there was no ceiling (Helmy 2008). In general, the high contribution rates charged by the system likely discourage participation on the part of both employees and employers. By comparison, contribution rates in other MENA countries, such as the Maghreb countries and Jordan, are much lower, ranging from 8 - $14 \%$ (Helmy 2008).

Another shortcoming of the current system is the means by which pensions are calculated. The fact that wages are calculated based only on the last years of service encourages workers and their employers to collude to underreport the employee's pensionable wage during their earlier years of service, then report their full wages only in the years immediately prior to retirement and thereby receive a higher pension (Loewe 2004). In some cases, employers also underreport their employees' pensionable wages in order to lower the value of the employer's required contributions (Maait et al. 2000). Maait et al. (2000) find that pensionable salaries in the government began to diverge markedly from pensionable salaries in the public and private production sectors, with the former increasing more rapidly than the latter during the second half of the I 980 os when privatization was beginning. Although not conclusive, this is consistent with a scenario in which salaries in the private sector are being underreported, which would cause growth in the pensionable salary to stall (regardless of trends 
in actual salary being paid). This issue will have significant implications for the financial sustainability of the social insurance system if not addressed.

A less obvious but perhaps even more important aspect of the current gaps in social insurance coverage is that unequal access to social protection mechanisms can actually increase socioeconomic inequality, particularly when social protection only reaches groups that are already fairly privileged in the labor market, such as formal sector workers, while failing to reach the most vulnerable, e.g. farmers and casual workers (Norton et al. 2002). Loewe (2004) argues that Egypt's social insurance system does in fact benefit the urban and middle classes more than the poorest segments of society, which are concentrated in rural areas and among the under - or unstably employed. In terms of the rural-urban divide, this assertion is certainly supported by the coverage figures discussed above. The World Bank (2007) finds that $80 \%$ of pension spending goes to the non-poor, which likewise supports the claim that social protection is not adequately combating inequality. It is also worth reiterating that self-employed and casual workers, who by the nature of their employment are likely exposed to greater job instability and wage fluctuations than formal sector wage employees, do not benefit from all of the social insurance benefits that formal sector workers do, including maternity leave, workplace disability compensation, and sickness coverage.

Finally, several types of problems with the structure and value of returns to pension contributions have been noted by different analysts. Early retirement criteria are quite lenient, and reductions made to the pension of workers who take early retirement are lower than what is actuarially sound (Loewe 2004; Helmy 2008). At the same time, returns to pension contributions are in general low (with the exception of the scheme for casual workers), despite the high contribution rates. This is due in part to the fact that pension values are not automatically adjusted for inflation, but rather are subject to periodic increases by the government (Maait et al. 2000; Loewe 2004). In the face of fairly high inflation rates, which peaked at $25 \%$ in I986, real pension values eroded significantly (Maait et al. 2000). More recent data from the Egypt Labor Market Panel Survey (ELMPS) indicate that pension values are low relative to the cost of living; among households receiving pensions in 2006 , the average monthly payment was 484 LE. ${ }^{14}$ These figures are comparable to those Loewe (2004) cites from the ILO in 1998 , finding that the average public sector employee received a pension of $4,727 \mathrm{LE}$ per year (356 LE per month), while the average private sector employee received I,716 LE per year (I43 LE per month).

14 Authors' calculations from the ELMPS. The accuracy of household reports of the value of their pension receipts has not been assessed. However, even substantial under-reporting of pension values is unlikely to cause such a large gap between average household receipts and the poverty line. 
However, when compared with national poverty line estimates from 2005 that categorize households with a monthly income of less than $994 \mathrm{LE}$ as extremely poor and those with less than I,423 LE as poor (World Bank 2007), both of these figures indicate that pension values are not nearly sufficient to maintain a household above or even at the poverty line.

\subsection{Towards a New Social Insurance System: Law 135 of 2010}

Prior the occurrence of the January $25^{\text {th }}$, 20 II revolution, a major reform of the social insurance system was scheduled to go into effect on January $\mathrm{I}^{\text {st }}$, 20I2. This reform, passed through Law 135 of 2010 , would gradually move Egypt from its current defined-benefits PAYG system to a definedcontribution notional accounts system (SSA 2OIO; Sabreen and Maait 2OII). Notional accounts are virtual individual accounts that record employees' contributions, which are then disbursed at the time of retirement with interest. The system also provides for solidarity accounts, to which a set percentage of each individual's contributions will be paid; if and when the individual's retirement account is exhausted, he or she may draw a certain amount from the solidarity fund (Sabreen and Maait 20II).

Law 135 also included a reduction in the contribution rates on basic wages to $11 \%$ for the employee and $19.5 \%$ for the employer (compared to the current $14 \%$ and $26 \%$, respectively) and eliminated the cap on the pensionable salary. These measures would effectively lower contribution levels for low-earning workers and raise them for high-earning ones (those earning more than about 3,000 LE per month). The law also provides for the regular adjustment of pensions for inflation, as long as the inflation rate is above $8 \%$ (Sabreen and Maait 20II). The new reform would raise the retirement age to 65 instead of 60 years old. This increase in age will occur gradually, with the retirement age set to $6 \mathrm{I}$ in 2015,62 in 2018, 64 in 2024 , and finally reaching 65 in 2027 (SSA 2010).

In addition to these changes in the contributory pension system, Law I35 would establish a minimum pension for all persons aged 65 or over who do not have another form of old-age support, regardless of whether or not they had participated in the pension scheme. This minimum pension would be equal to $15 \%$ of the national average wage. In an effort to encourage participation among informal sector workers, the government will contribute an additional amount equal to $25 \%$ of the individual's contributions to the pension accounts of seasonal workers and farmers. Finally, the law extends unemployment insurance, which would be available to all workers who have contributed to social insurance for at least $\mathrm{I} 2$ months. The maximum period for receiving unemployment benefits would be $\mathrm{I} 2$ months at a rate that gradually reduces over time 
from $65 \%$ of the average wage in the year prior to unemployment (Sabreen and Maait 20II).

\section{Health Insurance}

The ILO defines social health protection as "all public and private measures that aim at achieving universal access to health services" (ILO 2009: 6). Egypt has a fragmented health care system with several different types of service providers and funders that fit this definition. These include the social health insurance system, which is managed by the Health Insurance Organization (HIO), and a system of government hospitals and other healthcare facilities that provide services to the uninsured at highly subsidized rates (Maeda and El Saharty 2008). In this section we focus on the HIO, which is most closely linked to social insurance, as a full discussion of the subsidized government health care system is beyond the scope of this review. ${ }^{15}$

Health insurance coverage has been extended to different groups of the population under several different laws. Initially established in Alexandria in 1964, the system was intended to be expanded to cover the entire Egyptian population within ten years. However, it was only in 1975 that Laws 32 and 79 expanded health insurance to all government and public sector employees, as well as pensioners and those receiving survivors' benefits who chose to pay contributions (UNDP 2005). Law 32 covered government workers, whereas Law 79 covers public and private sector workers. Contributions for the latter group are higher, at $\mathrm{i} \%$ of the salary for the employee and $4 \%$ for the employer, than for the former, at $0.5 \%$ and $\mathrm{I} .5 \%$ of the salary for the employee and employer, respectively. Law 79 also extended health insurance coverage to pensioners and those receiving survivor benefits; pensioners pay $\mathrm{i} \%$ of their pension as a contribution and individuals receiving survivor benefits pay a contribution of $2 \%$ of the pension (Maeda and El Saharty 2008).

Health insurance eligibility was not expanded again until I992, when Law 99 of that year extended coverage to all students through high school. The contribution is $4 \mathrm{LE}$ per student, with the government making up the rest of the funding for this group. Finally, in 1997, Decree 380 extended coverage to pre-school age children with an enrollment contribution of 5 LE per child (UNDP 2005; Maeda and El Saharty 2008). Of these different categories of coverage, only workers covered under Law 32 and pre-school

15 More comprehensive discussions of the different components of Egypt's health care system can be found in Maeda and El Saharty (2008) and ILO (2009). 
aged children also must pay a token deductible (less than I LE) for health visits. For medications, workers covered under Law 32 pay $50 \%$ of the costs and both categories of children $33 \%$; workers covered under Law 79 do not pay any deductibles or contributions for medications (Maeda and El Saharty 2008).

The HIO operates its own network of health care facilities for its beneficiaries. It also contracts with additional private doctors to work in these facilities, with other private and public facilities for services, and with pharmacies, in order to provide additional services for those covered by health insurance (Maeda and El Saharty 2008). The other public health care schemes in Egypt also operate their own facilities, contributing to the fragmentation of service provision as well as funding for health care (Ministry of Health, Egypt and Health Systems 20/20 20IO).

\subsection{Coverage and Shortcomings of the Health Insurance System}

Citing the HIO annual reports for 2002/2003 and 2004, Maeda and El Saharty (2008) put the number of health insurance enrollees in 2005 at 3.74 million government employees, 3.29 million public and private sector employees, and I.75 million pensioners and those receiving survivor benefits, compared to 16.89 million students and 9.I4 million pre-school age children. These figures clearly demonstrate that the two groups of children comprise a much more substantial proportion of health insurance recipients $(8 \circ \%)$ than those who are enrolled due to current or past labor force participation.

Altogether, just over half of the population $(55 \%)$ was covered by health insurance as of $2007 / 08$, up from $35 \%$ in $1994 / 95$ (Ministry of Health, Egypt and Health Systems 20/2O 20IO). However, only a third of the labor force is covered by HIO, and Maeda and El Saharty (2008) estimate that less than $5 \%$ of private sector workers are covered. They attribute this in part to the fact that small and medium enterprises are not required to enroll their employees in health insurance, unlike social insurance.

Despite this increase in the percentage of the population covered by health insurance, financial analyses of Egypt's health care system agree that households pay for nearly two-thirds of health care expenditures in Egypt. The percentage of costs covered by households has been cited at $60.0 \%$ (Ministry of Health, Egypt and Health Systems 20/20 20IO) to $62.2 \%$ (Maeda and El Saharty 2008). The next largest source of financing is the government, at around $35.5 \%$ of health care costs, with the HIO managing only $8.06 \%$ of total health care finances. Out-of-pocket spending on health care has been growing faster than government spending; the percentage of health costs covered by households is up to its current levels from $5 \mathrm{r} \%$ 
of total health spending in 1994/95 (Maeda and El Saharty 2008; Ministry of Health, Egypt and Health Systems 20/20 2010). Poor households also spend a larger proportion of their income on health care than wealthier ones; Egyptian households in the lowest wealth quintile spend $10 \%$ of their household income compared to $7 \%$ among those in the highest wealth quintile (Salah 2007). This represents a significant financial burden on poor households, and exposes them to health shocks that can play a significant role in pushing vulnerable households into poverty (Norton et al. 2002).

As noted by Maeda and El Saharty (2008) the high proportion of health care costs borne by households may be related to several deficiencies in the HIO system, including the fact that some medical services are not covered by HIO, requiring patients to pay out-of-pocket, and the poor quality of government health services, which may push even those covered by HIO to seek private health care services. ${ }^{16}$ The ILO (2009) suggests that the large extension in coverage that resulted from Law 99 and Decree 380 may have placed a burden on the system that contributed to declines in quality, in part because the contributions required from these groups were not based on an actuarially sound analysis of the costs this expansion would entail.

In addition to the well-noted financial strains on the health care system and the associated issues with quality of service, several other elements of the HIO eligibility structure may restrict enrollment. One current shortcoming is that there is no provision for covering the dependents of HIO beneficiaries under the beneficiary's insurance. Although children under I 8 are now covered by the expansions of the I990s, there is no mechanism for providing coverage to children in university or women out of the labor force unless they are receiving survivors' benefits (Maeda and El Saharty 2008).

In general, health insurance and other programs intended to subsidize health care for those in need are poorly targeted. UNDP (2005), citing data from the Egyptian Ministry of Health and Population (MOHP), finds that while the combination of health care programs subsidizes just over $80 \%$ of health care costs for the two highest income quintiles, only about half of health care costs for those in the poorest wealth quintile are subsidized. Salah (2007), also citing MOHP data, puts this in the terms that $35 \%$ of government spending on healthcare goes to the wealthiest quintile, whereas only ${ }_{2} \%$ goes to the poorest. Healthcare spending is also biased in favor of men and urban areas due to the association between health insurance and formal sector, particularly government, employment.

In short, a lack of efficiency and equity in Egypt's current health

16 This suggestion is supported by the qualitative paper in this working paper series. See Sieverding (2012). 
care system, including health insurance, is an issue agreed upon by most analysts (UNDP 2005, Salah 2007, Maeda and El Saharty 2008, ILO 2009). Some effort to address this was made under the former regime through an initiative to expand and reform the health insurance system that was introduced in 2005. Among broader goals for improving the performance and financial sustainability of the health care system, the initiative aimed to extend social health insurance to all Egyptians and merge all of the components of the health care system into a national social health insurance scheme over the medium term (Salah 2007). Several draft laws were subsequently introduced to Parliament (see ILO 2009 for text), but the results of this initiative are unclear.

However, it is worth mentioning that at the end of July 2012 health insurance coverage was extended to all women heads of household through a law that was passed by the new Parliament on May 26 of the same year. To be covered by the law, women must meet certain eligibility criteria: being the head of the household, having no source of income or an income that does not exceed $150 \%$ of the social pension value ("ma'ash al daman", see next section), and being outside of the health insurance system. The beneficiary population is estimated at around 5 million women, who will be eligible to enroll in the health insurance system by paying a contribution of I2 LE or I\% of their annual income. The government will subsidize this contribution by paying the health insurance system 200 LE for each beneficiary. ${ }^{17}$

\section{Social assistance}

Egypt's social assistance program is administered by the Ministry of Social Affairs (MOSA). Along with the food subsidy program and the Social Fund for Development, it is considered one of Egypt's three main safety nets.However, it receives by far the smallest portion of the total budget allocated to these three programs (only 2\%) (Sabry 2005). Social assistance is administered as a monthly non-contributory pension; originally named Sadat pensions, the program was renamed Mubarak pensions, and are now officially called MOSA Social Solidarity pensions, "I8 "ma'ash al daman," although often still popularly referred to by previous names.

17 http://shorouknews.com/news/view.aspx?cdate=29072012\&id=872e8e55-1d85-4a90-8023-fb9aeff83e6b

18 Interview with a representative of the Social Insurance Administration, 25 June 2012. 
The non-contributory pension system was established by Law II2 of I980, the same law that legally extended social insurance coverage to casual workers (Helmy 2008). To be eligible, individuals must not be receiving another type of pension, and must be considered part of one of society's most vulnerable groups, including divorced, widowed, and abandoned women, other women with no male provider, orphans, the elderly, and households in which the male head is unable to work (Sabry 2005). In short, the pensions are targeted toward households with no male provider capable of earning a labor income.

The value of the non-contributory pension is determined by the size and composition of the beneficiary household. According to Sabry (2005), in the early 2000 s this ranged from 50 LE per month for an elderly person on their own to $70 \mathrm{LE}$ per month for a disabled man with three children. The pension value was increased to I24 LE per month prior to the January, $25^{\text {th }}$ revolution. Then, shortly after the revolution, the new Ministry of Finance further raised the pension to 200 LE per month. ${ }^{19}$ Most recently, after the 2012 presidential elections, the new President Mohammed Morsi increased the pension value to a maximum of 300 LE per month per household. The pension value will be determined by household size; a oneperson household will now receive $215 \mathrm{LE}$ per month, compared to $145 \mathrm{LE}$ prior to the increase. Pension values for two- and three- and four-person households will increase from $\mathrm{I} 60 \mathrm{LE}$ to $240 \mathrm{LE}, \mathrm{I} 85 \mathrm{LE}$ to $275 \mathrm{LE}$, and 205 to $300 \mathrm{LE}$, respectively. ${ }^{20}$

\subsection{Coverage, Targeting and Shortcomings of the Social Assistance System}

The current non-contributory pension scheme suffers from several serious shortcomings, including limited coverage, very low pension values, and bias in administration. Among the current generation of older households in which the head is age 60 or above, only $12.7 \%$ were receiving a non-contributory pension in 2006 , compared to $63.4 \%$ that were receiving a public contributory (social insurance) pension. Receipt of non-contributory pensions is concentrated among female-headed households, of whom $15.6 \%$ were receiving a pension in 2006 , compared to $4.4 \%$ of male-headed households. As shown in Table 4 , receipt of noncontributory pensions is higher among female headed households at all age groups, reaching a high of $19.3 \%$ among those in which the head is age 60 or older. This is to be expected, as rates of widowhood are likely

19 http://www.egynews.net/wps/portal/news?params=127944

20 http://www.shorouknews.com/news/view.aspx?id=a0a18a65-d36f-46ce-9430-7cafd7a442e5 
to increase with age, expanding the population of women eligible for a pension. Non-contributory pensions are also more prevalent in rural areas, where poverty rates are higher than in urban ones (World Bank 2007), and particularly among rural female headed households. ${ }^{2 \mathrm{I}}$

Table 4: Percentage of households currently receiving a non-contributory pension, by age and sex of household head and region of residence

\begin{tabular}{|lcc|}
\hline & Male Head of Household & Female Head of Household \\
\hline Age Group & & \\
$25-29$ & 2.2 & 2.9 \\
$30-39$ & 2.9 & 8.6 \\
$40-49$ & 4.3 & 18.0 \\
$50-59$ & 2.9 & 15.8 \\
$60+$ & 9.7 & 19.3 \\
\hline Residence & & \\
Urban & 1.9 & 8.2 \\
Rural & 6.7 & 24.1 \\
\hline Total & $\mathbf{4 . 4}$ & $\mathbf{1 5 . 6}$ \\
\hline
\end{tabular}

Source: Authors calculations from the 2006 Egypt Labor Market Panel Survey

This distribution of non-contributory pensions represents both the failure to cover most poor households and a substantial leakage of funds to non-poor households. The World Bank estimates that public social assistance reaches less than ${ }_{2} \%$ of Egypt's poor (2006), and that as much as $70 \%$ of social assistance payments go to the non-poor (2007). Although pension receipt should legally be means-tested through household visits, the ability to carry this out effectively may be weak (World Bank 2006). On the other hand, ethnographic accounts suggest that determination of whether an applicant meets the means eligibility criteria is based on the subjective judgment of MOSA employees (Bibars 200I; Sabry 2005). Bibars (200I) also finds that access to pensions is complicated by the fact that many women do not have IDs, and that application procedures are long and burdensome. She also documents the norms of male providership that are deeply embedded in the social assistance program and the attitudes of those who administer it, leading to biases that restrict effective access for some eligible groups of women (such as those who were abandoned by their husbands or are deemed pretty enough to remarry) as well as humiliation for those completing the application process.

21 Authors' calculations based on the 2006 Egypt Labor Market Panel Survey (ELMPS). 
In addition, the values of non-contributory pensions described above are extremely low. Data from the ELMPS indicate that on average, households receiving a non-contributory state pension in 2006 received $78 \mathrm{LE}$; 80.5 LE on average among male headed households and $74.8 \mathrm{LE}$ among female headed households. ${ }^{22}$ Based on the World Bank (2007) poverty lines cited above, this means that the average social assistance pension is equal to $7.8 \%$ of the 'very poor' poverty line and $5.5 \%$ of the 'poor' poverty line. This is very similar to the figure cited by the World Bank itself that social assistance provides a benefit equal to $8 \%$ of the poverty line for a family of five in Upper Egypt (2006). Sabry (2005), using a range of poverty lines and pension values based on family size, finds that pensions vary from $6 \%-55 \%$ of the poverty line depending on the definition used. Even the maximum social assistance pension of $300 \mathrm{LE}$ under the recently implemented increase corresponds to only $30.2 \%$ of the World Bank's 'very poor' poverty line and 2I.I\% of the 'poor' poverty line in 2007.

Several other types of social assistance programs have been piloted in Egypt recently, drawing on the growing international body of innovative research and programming in this area. A Conditional Cash Transfer program is being piloted in Ain es Sira, a slum of Cairo. ${ }^{23}$ In 2008 , the Ministry of Social Solidarity, in collaboration with many other ministries, also began a strategy to identify and improve living conditions in Egypt's I,O०O poorest villages through an integrated program that addresses health, housing and local development, water and sanitation, primary education, job opportunities for youth, and small and medium enterprise development (UNDP 20IO). Additional efforts to expand the scope and efficacy of social assistance programs are urgently called for in order to expand social protection access to a greater portion of the population.

\section{Conclusions and Policy Recommendations}

This review of Egypt's social protection policies, which encompassed social insurance, health insurance, and social assistance, has highlighted that across these three key areas, it is not the legal framework but rather the efficient and equitable management of social protection mechanisms that is the greatest challenge moving forward. In the face of incomplete and inequitable coverage across different groups of the population, and the low value of benefits provided, Egypt's social protection system faces not only

22 Authors' calculations from the ELMPS.

23 See http://www.pathwaysofempowerment.org/research_empowering_projects.html\#CashTransfers 
significant financial challenges, but also the prospect that participation will come to be viewed as a poor investment or irrelevant to households' needs. This will only encourage evasion of a social insurance system that already suffers from declining coverage, and will continue to push the burden of health care costs onto over-stretched household budgets. Most importantly, it leaves a significant portion of Egypt's poorest and most vulnerable population without access to the social protection mechanisms needed to sustain their livelihoods.

Although a number of studies have made recommendations for the reform of the social insurance, health insurance or, to a lesser extent, social assistance systems in Egypt, it is important to remember that these three systems interact with one another and changes to any one may have unintended impacts on the others. The design of any new social assistance program targeting those who are excluded from contributory social protection programs should take into consideration the potential to reduce incentives for enrolling in social insurance. Several studies from Latin America, for example, have found that in the case of female wage workers in Mexico City (Juarez 2008) and among workers in several cities of Colombia (Camacho et al. 2009), reforms instituting free health care were associated with a negative effect on workers' likelihood of being enrolled in social security and health insurance, respectively. For such reasons, social protection reform should be approached holistically, with careful consideration of how reforms to any one of the three major systems might positively or adversely affect the coverage of the others, as well as progress toward the overall goal of providing universal access to social protection.

That said, there are several policy measures that should be considered for each of the three major systems described. Some of the recommendations below draw from literature on the Egyptian case specifically, some from the experience of other developing countries. However, whenever studying social protection reform measures adopted by other countries, regardless of their degree of success, it is important to consider the applicability of these measures to the local context. And, to reiterate, all of the recommendations below should be considered in terms of their potential effects on progress toward the overall goal of extending social protection access to all Egyptians.

\section{Social Insurance}

As highlighted in the discussion above, the social insurance system faces a number of challenges in terms of efficacy and equity. Policy measures to address these challenges can be loosely grouped into the three interrelated categories of strengthening the link between contribution and 
benefit levels, expanding coverage, and improving the administration of the system.

Linking benefits more closely to workers' contributions is critical not only for the long-term financial sustainability of the system, but also for improving the transparency of the system and encouraging enrollment. An important step towards strengthening the contributions-benefits link is to implement the notional accounts system proposed under Law 135 of 20IO. Again, this system would establish individual virtual accounts into which workers' contributions would be deposited, to be then dispersed as pension benefits with interest upon retirement (Sabreen and Maait 20II). A move to a notional accounts system would have several important advantages. In addition to being actuarially sounder, a notional accounts system should improve returns to pension contributions, and allow workers to see a more direct link between what they have paid and their retirement benefit (Ribe et al. 20IO). With a clear link between contributions and benefits, workers will better be able to see how their contributions are in fact a form of investment for the future (of course, this investment must be earning a reasonable return for this to be the case). Furthermore, pension values would no longer be based only on the last years of service, but rather on the entire period of contributions. This will reduce the incentive for employees to under-report their wages during their earlier years of employment (Sabreen and Maait 20II).

The overall reduction in contribution rates proposed under Law 135 of 20 IO should also be implemented as high contribution rates may serve as a disincentive for enrollment among workers and employers (Loewe 2004; Helmy 2008). At the same time, the calculation of benefits should be revisited in line with a new notional accounts system. It is important that benefit levels reflect a fair return to workers' contributions. In order to achieve this, benefit levels should be 'automatically' adjusted for inflation rather than subject to periodic increases that may not reflect actual changes in the cost of living (Mait et al. 2000, Loewe 2004). Pension values should also be adjusted for changes in life expectancy. Finally, as it has been well-noted that the reductions in pension values for early retirees are not actuarially sound, an adjustment to early retirement benefits rates should also be examined (Loewe 2004; Helmy 2008).

Another element of Law 135 of 2010 that should be implemented is the elimination of the ceiling on pensionable wages. As noted above, this ceiling acts as a regressive tax and is a factor contributing to low pension values. It also means that the social insurance system is forgoing contributions on a significant part of high-earners' wages. Removing this ceiling is therefore an important step towards improving the link between contributions and benefits (Helmy 2004, 2008). 
All of the measures discussed above will have the effect of improving the return to social insurance contributions, and should thereby create a greater incentive for workers to enroll. In other words, improving the link between contributions and benefits is also the first step towards expanding social insurance coverage among groups that currently see participation as too expensive or a poor investment. More direct incentives can also be provided to encourage informal workers and the self-employed to enroll in social insurance. For example, under Law 135 of 2010 , an additional measure was to be put in place under which the government would provide a matching contribution equal to $25 \%$ of the worker's contributions to the accounts of farmers and seasonal workers who enrolled in social insurance (Sabreen and Maait 20II). This measure should be piloted and studied in order to measure its potential to improve participation among the most vulnerable groups of workers, including but not necessarily limited to those groups identified under Law 135 of 20IO. In doing so, it is important that incentives be structured carefully so as to encourage savings and not to discourage the movement of vulnerable workers into more stable forms of employment.

In addition to informal workers, women are a group with relatively low rates of individual access to social insurance because of their low levels of labor force participation. On the one hand, expanding social insurance coverage among male workers will increase the percentage of women who are eligible for survivors' benefits. However, individual rather than household-level access to benefits may be more effective in terms of reducing women's vulnerability (Sabates-Wheeler and Kabeer 2003). Therefore, options should be explored for establishing a voluntary, contributory pension fund for women who are out of the labor force. Such a fund might allow women to contribute at a chosen level, like the current system for the self-employed, perhaps with some level of matching benefits from the state to encourage participation. Again, the potential effects of such a system on women's labor force participation, and participation in the regular pension fund or social assistance, would have to be carefully explored.

Finally, improving the administration of the social insurance system will require improved enforcement of social insurance law. The negative effects of evasion on both the financial health of the system and workers' access to social protection have been well-noted (Mait et al. 2000; Loewe 2004; Helmy 2004, 2008). Another important step towards more efficient administration is the computerization of the social insurance system. This would entail providing each worker with a unique social insurance number, similar to the current system for national ID numbers, to which all contributions would be linked. Computerization would help streamline 
NOSI record-keeping and allow for easy tracking of workers' progress towards the minimum $\mathrm{I} 2 \mathrm{O}$ months of contributions, as well as their contribution levels, even when workers change jobs frequently. Moving to a computerized system is particularly important in the event that Egypt does move to a notional accounts system, as this type of system requires high administrative capacity as well as careful management of funds independently of the regular state budget (Helmy 2004).

An additional benefit of computerization is that workers could then be provided access to their individual records, either through an online system or public information desks. Workers could then view their own records and know how many months they need for pension eligibility. The system could also provide estimates of the individual's future pension value based on current contributions, and additional voluntary contributions if they were made, allowing workers to see more the link between their contributions and benefits. It may also encourage workers, and particularly the self-employed, to increase their contributions in order to receive a larger pension in the future. An experiment to provide such online access to social insurance records is currently being conducted on the NOSI website; this approach should be piloted and rigorously evaluated for potential expansion.

\section{Health Insurance}

In the medium - to long-term, a systematic reorganization and unification of Egypt's national health care system needs to be undertaken in order to improve the efficiency and efficacy of the system (see Maeda and El Saharty 2008 for a more extensive discussion of this issue). This process should include a full review of the role of the HIO in providing and paying for health care. Expanding health insurance coverage should be an important aim of any reform of the health insurance system. However, it is equally important that quality of services be improved, as this has been widely noted as a major problem in the current system. The poor quality of services for health insurance beneficiaries also serves as a disincentive to participation (Sieverding 20I2), which will inhibit any attempts to expand coverage.

One measure that could be undertaken in the short- to medium- term to expand health insurance coverage - as long as the implications for quality of service are adequately dealt with - is the extension of coverage to all dependents of current health insurance beneficiaries that are not already covered. As Maeda and El Saharty note (2008), this would entail relatively less administrative burden than other methods of coverage expansion because the main insurance holder is already registered with 
HIO. Providing coverage to dependents might also increase the appeal of health insurance for workers. In Uruguay, for example, Cruces and Bergolo (20II) found that the extension of health insurance benefits to the dependents of workers registered with the social insurance system (which provides pension, health and other benefits in a single package) decreased rates of informality. The authors conclude that workers thus responded positively when additional incentives were built into the social insurance system.

\section{Social Assistance}

In order to serve as an effective form of social protection for Egyptian society as a whole, the social assistance system must expand coverage to the poor while reducing the leakage of benefits to those who do not need them. An important step that can be taken towards expanding coverage is implementation of the minimum pension clause stipulated in Law I35 of $20 \mathrm{IO}$, in order to provide social protection access to all elderly individuals. This expansion, which would make men over age 65 eligible for social protection, may also help counter the perception that non-contributory pensions are only for women with no provider. As noted in the literature on gender and social protection (Sabates-Wheeler and Kabeer 2003), targeting programs towards narrow groups, including women with no provider, may have a stigmatizing effect on social assistance.

Another means of reaching more poor households through social assistance, while reducing the degree to which social assistance is targeted to women without a male provider, is to expand eligibility criteria to include all very poor households even if an able-bodied male head is present. Any such expansion would have to carefully consider the potential to create a dis-incentive for labor force participation, but could have the potential to dramatically increase the percentage of poor households that have access to social assistance. Improving the capacity of the Ministry of Social Affairs to conduct accurate and fair means-testing of social assistance applicants would also be an important step towards reducing leakages to the non-poor while expanding social assistance coverage.

In addition to expanding coverage, social assistance benefits must be brought more in line with the cost of living in order to afford beneficiaries a decent living. The recent increases implemented since the January $25^{\text {th }}$, 20 II revolution are important steps in this direction. However, benefit amounts remain significantly below the poverty line. The periodic increasing of benefit levels also has the effect of politicizing the social assistance system, turning increases into a gesture of government charity rather than incorporating them as part of a well-functioning social 
assistance system that is a welfare right for vulnerable groups (Sabry 2005). As with social insurance, social assistance benefit amounts should therefore be linked to a consumer price index and adjusted automatically with inflation. If implemented, the minimum pension for citizens over age 65 should be subject to the same process. Although the minimum pension is tied the national average wage, the proposed $15 \%$ bar may be quite low in monetary terms. The adequacy of this standard for supporting a household should be studied, and the alternative of linking the minimum pension to a price index rather than wage levels considered.

Finally, a growing body of international literature suggests that a move towards conditional forms of social assistance that aim to build the human capital of poor households can be a more empowering and, over the long run, effective means of reducing poverty (Barrientos et al. 20I0).24 By requiring investments in health and education, Conditional Cash Transfers and similar mechanisms may have more empowering effects for beneficiary households. Investments in children spurred by CCT programs also have the potential to reduce the intergenerational reproduction of poverty. The current CCT pilot program in Ain es Sira is a positive step towards exploring the potential of this new generation of social assistance programs for Egypt, and other innovative, developmentoriented social assistance programs should be encouraged and piloted.

24 Barrientos et al. 2010 provide a comprehensive listing of social assistance programs around the world, including objectives, targeting, and a summary of results from evaluations when these are available. References to program-specific documents and evaluation reports are also provided. 


\section{References}

Ahmed, Akhter U., Howarth E. Bouis, Tamar Gutner and Hans Lofgren. 200I. The Egyptian Food Subsidy System: Structure, Performance and Options for Reform. Research Report II9. Washington, D.C.: International Food Policy Research Institute.

Assaad, Ragui, ed. 2009. The Egyptian Labor Market Revisited. Cairo: American University in Cairo Press.

Assaad, Ragui. 2009. Labor Supply, Employment and Unemployment in the Egyptian Economy, 1988 - 2006. In The Egyptian Labor Market Revisited, ed. Ragui Assaad, I - 52. Cairo: American University in Cairo Press.

Assaad, Ragui, and Fatma El Hamidi. 2009. Women in the Egyptian Labor Market: An Analysis of Developments, 1988-2006. In The Egyptian Labor Market Revisited, ed. Ragui Assaad, II7-156. Cairo: American University in Cairo Press.

Barrientos, Armando and David Hulme. 2009. Social protection for the poor and poorest in developing countries: Reflections on a quiet revolution. Oxford Development Studies 37 (4): 439- 456.

Barrientos, Armando, Miguel Nino-Zarazua, and Mathilde Maitrot. 2010. Social Assistance in Developing Countries Database, Version 5.o. Brooks World Poverty Institute, University of Manchester. Available at: http://www.chronicpoverty.org/publications/details/social-assistance-indeveloping-countries-database/ss

Camacho, Adriana, Emily Conover and Alejandro Hoyos. 2009. Effects of Colombia's Social Protection System on Workers' Choice between Formal and Informal Employment. University of the Andes, Documentos CEDE. Available at: http://ideas.repec.org/p/col/000089/006003.html

Cruces, Guillermo and Marcelo Bergolo. 20II. Labor informality and the incentive effects of social protection systems: Evidence from a health reform in Uruguay. Washington, D.C.: Inter-American Development Bank.

Fattouh, Bassam and Laura El Katiri. 2012. Energy Subsidies in the Arab World. Arab Human Development Report Research Paper Series. New York: United Nations Development Programme.

Helmy, Omneia. 2004. Development of the pension system in Egypt (in Arabic). Working Paper. Cairo: Egyptian Center for Economic Studies.

--- 2008. Toward a more efficient and equitable pension system in Egypt. In The Egyptian Economy: Current Challenges and Future Prospects, ed. Hanaa Kheir el-Din, 20I-234. Cairo: American University in Cairo Press.

International Labour Organization (ILO). 2009. ILO considerations on the social health insurance reform project in Egypt. Geneva: ILO. 
Juarez, L. 2008. Are Informal Workers Compensated for the Lack of Fringe Benefits? Free Health Care as an Instrument for Formality. Working Paper 0804. Mexico City: Centro de Investigación Económica, ITAM. Available at: http://ideas.repec.org/p/cie/wpaper/0804.html

Kabeer, Naila. 2009. Scoping study on social protection: Evidence on impacts and future research directions. London: DFID.

Loewe, Markus. 2004. New avenues to be opened for social protection in the Arab world: The case of Egypt. International fournal of Social Welfare I3: 3- I4.

Maait, Mohammed A., Gala Ismail and Zaki Khorasanee. 200o. The effects of privatization and liberalization of the economy on the actuarial soundness of the Egyptian funded and defined benefits social security scheme. Paper presented at the Year 2000 International Research Conference on Social Security, Helsinki, Finland, 25- 27 September.

Maeda, Akiko and Sameh El Saharty. 2008. In The Egyptian Economy: Current Challenges and Future Prospects, ed. Hanaa Kheir el-Din, 30I - 33 I. Cairo: American University in Cairo Press.

Ministry of Health, Egypt and Health Systems 20/20. 2010. National bealth accounts 2007/2008: Egypt report. Bethesda, MD: Health Systems 20/20 project, Abt Associates Inc.

Ministry of Social Insurance. 2003. The problem of evasion from social insurance contributions (In Arabic). Unpublished report.

Norton, Andy, Tim Conway and Mick Foster. 2002. Social protection: Defining the field of action and policy. Development Policy Review 20 (5): $54 \mathrm{I}-567$.

Ribe, Helena, David A. Robalino and Ian Walker. 20IO. Achieving Effective Social Protection for All in Latin America and the Caribbean: From Right to Reality. Washington, DC: World Bank.

Sabates-Wheeler, Rachel and Naila Kabeer. 2003. Gender equality and the extension of social protection. Extension of Social Security Paper No. I6. Geneva: ILO.

Sabreen, Mervat Abd Es Salem, and Mohammed Mait. 20II. Reforming Egypt's social security system: A vision for social solidarity. Social Security Observer I3 (June 20II). Geneva: International Social Security Association. Available at: http://news.issa.int//layout/set/print/newsletter/newsletter_ repository/observer/en/social_security_observer_13

Sabry, Sarah. 2005. The social aid and assistance programme of the government of Egypt - a critical review. Environment and Urbanization 17 (2): $27-4$ I.

Salah, Hassan. 2007. Mapping of healthcare financing in the Eastern Mediterranean region. Cairo: WHO. 
Sieverding, Maia. 2012. A life course perspective on social protection in Egypt. Working paper. Cairo: Population Council.

Social Security Administration (SSA). 2010. International update: Recent developments in foreign public and private pensions (July 2010). Washington, D.C.: Social Security Administration.

--- 20II. Social Security Programs around the World: Africa, $20 I I$. Washington, D.C.: Social Security Administration.

United Nations Development Programme (UNDP). 2005. Egypt Human Development Report 2005 - Choosing our Future: Towards a Nerw Social Contract. Cairo: UNDP.

---. 2010. Egypt Human Development Report 2010 - Youth in Egypt: Building our Future. Cairo: UNDP.

van Ginneken, Wouter. 2003a. Social security for the informal sector: A new challenge for the developing countries. International Social Security Review 52: 49-69.

van Ginneken, Wouter. 2003b. Extending social security: Policies for developing countries. Extension of Social Security Paper No. I3. Geneva: ILO.

World Bank. 2006. Opportunity, Security and Equity in the Middle East and North Africa. Spectrum Summer 2006. Washington, D.C.: World Bank.

--- 2007. Arab Republic of Egypt Poverty Assessment Update. Report No. 39885 - EGT. Washington, D.C.: World Bank.

--. 2010. Egypt's Food Subsidies: Benefit Incidence and Leakages. Cairo: World Bank. 



